\title{
Down-regulation of androgen-receptor and PSA by phytochemicals
}

\author{
SOPHIE CHEN ${ }^{1}$, JIAN GAO, H. DOROTA HALICKA, FRANK TRAGANOS and ZBIGNIEW DARZYNKIEWICZ \\ Department of Medicine, New York Medical College, Valhalla, NY 10595, USA
}

Received September 10, 2007; Accepted November 5, 2007

\begin{abstract}
The androgen receptor (AR) signaling pathway continues to be active in hormone resistant prostate cancer (HRPC) and can inappropriately activate transcription. Consequently the AR is a therapeutic target for HRPC. We reported that PC-SPES is active against HRPC, partly due to its actions in down-regulating AR protein expression and modulating cell cycle. Further investigation has identified five active anticancer compounds. This study describes the effects of three of these compounds (oridonin, isoliquiritigenin and wogonin) on cell proliferation, cell apoptosis, cell cycle parameters, AR and PSA protein expression. In each case, these compounds have independent activities which may partly contribute to the biological activity of PC-SPES.
\end{abstract}

\section{Introduction}

Prostate cancer is the second most common cancer among American men and early intervention including androgen ablation therapy has yielded good responses (1). However, almost all patients in this group eventually become refractory to androgen ablation therapy (HRPC) (2).

Recent studies show that cancer progression and metastasis lead to alteration in the vast majority of androgen receptor pathway genes (3-8). Although HRPCs become insensitive to androgen ablation therapy, AR and the AR related gene, PSA, continue to be expressed and the AR signal pathway remains active (8). As a result, AR can inappropriately activate transcription in androgen independent prostate cancer cells via mechanisms that are resistant to castration and AR antagonism (9-12). Based on these observations, deleting or inactivating AR appears to be an attractive option for HRPC patients (13-15).

Correspondence to: Dr Sophie Chen, ${ }^{1}$ Present address: The Ovarian and Prostate Cancer Research Trust Laboratory, Surrey Technology Centre University of Surrey, Guildford, Surrey GU2 7YG, UK

E-mail: s.chen@opcart-lab.org

Key words: antiproliferation, apoptosis, cell cycle, androgen receptor, prostate specific antigen, hormone refractory prostate cancer
During the period 1997 to 2002, PC-SPES, a mixture of extracts from eight herbs (Dendrantherma morifolium, Ganoderma lucidium, Glycyrrhiza uralensis, Isatis indigotica, Panax pseudo-ginseng, Rabdosia rubescens, Scutellaria baicalensis and Serenoa repens) was reported to inhibit prostate cancer cell growth in vitro and reduce PSA in patients with HRPC (16-24). This product was withdrawn from the market in 2002 due to concerns over batch variability (25).

Previously, we reported that one of the mechanisms for the activity of PC-SPES against prostate cancer could be attributed to its ability to down-regulate $\operatorname{AR}(26,27)$. We subsequently demonstrated that one of the antiproliferative agents in PC-SPES, baicalin or its aglycon baicalein, down-regulated the AR protein in the $\mathrm{LNCaP}$ cell line in a dose-dependent manner. In this study, we describe additional antiproliferative agents identified in PC SPES, which exhibit similar activities in inhibiting prostate cancer cell growth, inducing apoptosis, modulation of cell cycle and downregulation of the protein expression of AR and PSA.

\section{Materials and methods}

Chemicals and reagents. Isoliquiritigenin (ISL), wogonin and oridonin directly isolated from PC-SPES and identified by HPLC (Shimadzu SPD-M10A), GC-MS (HewlettPackard VG 7070) and proton and carbon 13 NMR spectrum (Varian Inova 400) were used in the MTT assay. For cell cycle and AR studies, ISL was purchased from Sigma (St. Louis, MO), wogonin and oridonin were purchased from Zhao-Wei Technology Development Co. (Shanghai, China). Stock solutions of oridonin, ISL and wogonin at $10 \mathrm{mg} / \mathrm{ml}$ were prepared in $95 \%$ ethanol and stored at $-20^{\circ} \mathrm{C}$ under nitrogen.

Cell culture. LNCaP and DU-145 were purchased from American Type Tissue Collection, Rockville, MD. Cells were maintained in RPMI-1640 medium supplemented with $10 \%$ fetal calf serum, 100 units $/ \mathrm{ml}$ penicillin, $100 \mathrm{mg} / \mathrm{ml}$ streptomycin, and $2 \mathrm{mM}$ L-glutamine (all from Gibco/BRL Life Technologies).

Determination of cell proliferation. The MTT assay was performed to study the effect of ISL and wogonin on the cell growth of LNCaP and DU-145 cells. The MTT reagent kit was purchased from Boehringer Mannheim (Roche Diagnosis Corp., Indianapolis, IN) to count viable cells. 
Tetrazolium dye (MTT) is cleaved to form formazan by metabolically active cells and exhibits a strong red absorption band at 550-618 $\mathrm{nm}$. The protocol for the cell viability assay was provided by the manufacturer and modified in our laboratory as described below .

Cells were seeded in 96-well microtiter plates at a concentration of $6 \times 10^{3}$ for DU-145, $10 \times 10^{3}$ for LNCaP, $4 \times 10^{3}$ for MCF-7 and $12 \times 10^{3}$ cells for AT2780 per well, in a volume of $100 \mu 1$ of cell culture medium. After 24 h, $20 \mathrm{ml}$ aliquots of the compounds at various concentrations were added to the attached cells. Each concentration was plated into 3 wells to obtain mean values. To eliminate any solvent effect, $20 \mathrm{ml}$ of the solvent used in the preparation of the highest concentration of the compounds (a maximum of $0.5 \%$ by volume of DMSO) was added to the control cells in each well. The plates were incubated at $37^{\circ} \mathrm{C}$ in the $\mathrm{CO}_{2}$ incubator for $72 \mathrm{~h}$. At the end of day 3 , the culture medium was carefully removed without disturbing the cells, and replaced by $100 \mu 1$ of fresh cell medium. Ten microliters of MTT reagent was added to each well and the plates were incubated again in the $\mathrm{CO}_{2}$ incubator at $37^{\circ} \mathrm{C}$ for $4 \mathrm{~h}$. SDS solublizing reagent (100 $\mu \mathrm{l}$ ) (Boehringer Mannheim) was added to each well. The plate was allowed to stand overnight in the $\mathrm{CO}_{2}$ incubator and read by ELISA Reader (EL800, Bio-Tek Instruments, Inc.) at a wavelength of $570 \mathrm{~nm}$. The percent cell viability was calculated according to the equation below: 100\% (absorption of the control cells - absorption of the treated cells/absorption of the control cells). By definition, the viability of the control cells, from the untreated cell cultures, was defined as $100 \%$.

Sample preparation for cell cycle measurement. Cultured LNCaP and DU-145 (2-4x106 cells) cells were exposed to varying concentrations of ISL for 24 and $48 \mathrm{~h}$ (in $12.5 \mathrm{~cm}^{2}$ area flask) before being harvested. The cells were washed with PBS and fixed in ice-cold $70 \%$ ethanol. Aliquots of fixed cells were re-hydrated into PBS and stained with $1.0 \mathrm{mg} / \mathrm{ml}$ DAPI (4,6-diamidino-2-phenylindole from Eastman Kodak, Rochester, NY) dissolved in $10 \mathrm{mM}$ piperazine-N, N-bis-2ethane-sulfonic acid buffer (Calbiochem, La Jolla, CA) containing $100 \mathrm{mM} \mathrm{NaCl}, 2 \mathrm{mM} \mathrm{MgCl}$ and $0.1 \%$ Triton X-100 (Sigma) at pH 6.8.

Analysis of cell cycle distribution. Cellular DNA content, after cell staining with the DNA specific fluorochrome DAPI, was measured with an ELITE ESP flow cytometer (Coulter Inc., Miami, FL) using UV laser illumination. The Multicycle program (Phoenix Flow Systems, San Diego, CA) was used to deconvolute the DNA frequency histograms to estimate the frequency of cells in different phases of the cell cycle and in apoptosis. The experiments were repeated several times, yielding essentially identical results.

Western blot analysis of AR concentration in LNCaP. Western blot analysis was used to measure the concentration of AR protein in LNCaP cells following growth for $48 \mathrm{~h}$ in the absence and presence of oridonin, ISL and wogonin. Equal amounts of protein $(10 \mathrm{mg})$ from LNCaP cell lysates were applied to $10 \%$ SDS/PAGE gel, and were then transferred to PVDF membranes (actin was used as a loading control). The blots were probed with primary mouse anti-human antibodies from DAKO (1:100 anti AR) followed by a 1-h incubation with a 1:1000 dilution of the labeled secondary antibody anti-mouse IgG-HRP (Santa Cruz Biotechnology, USA). The antibody binding was detected using chemiluminescence (ECL Western blotting system). The experiments were run in duplicate.

Western blot analysis of PSA concentration in LNCaP. Western blot analysis was used to measure the concentration of PSA protein in LNCaP cells following the growth in the absence and presence of ISL and wogonin. The protocol is similar to that for AR analysis. The blots were probed with primary mouse anti human antibodies from DAKO (1:400 anti-PSA) followed by a 1 -h incubation with a 1:1500 dilution of the labeled secondary antibody, anti-mouse IgG-HRP (Santa Cruz Biotechnology). The antibody binding was detected using chemiluminescence (ECL Western blotting system). The experiments were run in duplicate.

Flow cytometric measurement of AR concentration. Following treatment with oridonin (3-9 $\mathrm{mM}$ ) for $48 \mathrm{~h}$, the cells were trypsinized, washed with PBS, fixed in $1 \%$ formaldehyde in PBS on ice for $10 \mathrm{~min}$ and then permeabilized with $70 \%$ ethanol at $-20^{\circ} \mathrm{C}$. After fixation, the cells were rinsed with PBS, treated with a blocking solution containing $1 \%(\mathrm{w} / \mathrm{v})$ bovine serum albumin (BSA) and $0.1 \%$ sodium azide in PBS (PBS-BSA) for $2 \mathrm{~min}$ at room temperature. The cells were subsequently added to a 100-ml aliquot of BSA/PBS solution containing 1:50 diluted primary antibody from DAKO (mouse anti-human) for AR. The mixtures were incubated at room temperature for $1 \mathrm{~h}$ in the dark. The cells were subsequently washed twice with PBS-BSA buffer. The secondary antibody from DAKO conjugated to FITC (goat anti-mouse) was added at a dilution of 1:50 for $30 \mathrm{~min}$ at room temperature in the dark. Then cells were counterstained for DNA by $1 \mathrm{ml}$ of PI solution (final PI concentration $5 \mathrm{mg}$ / $\mathrm{ml}$ ) containing $100 \mu \mathrm{g} / \mathrm{ml}$ of RNase A. Cellular fluorescence was measured with the ELITE ESP flow cytometer/cell sorter using the argon ion laser (emission at $488 \mathrm{~nm}$ ). Fluorescence signals were collected using the standard configuration of the flow cytometer (green fluorescence for antibodies against AR and red fluorescence for DNA staining). The fluorescence intensities of ten thousand cells were measured per sample.

Apoptosis induced by ISL and wogonin. The prostate cancer cells, LNCaP and DU-145, were counterstained with DNA specific fluorochrome DAPI and viewed under mixed illumination, combining UV light excitation and Nomarski interference contrast fluorescence microscope (Nikon Microphot).

Inhibition of cyclooxygenase (COX) activity by ISL. The direct effect of ISL on the enzymatic activity of COX 1 and COX 2 was assayed following the protocol provided by the commercial assay kit from Cayman Chemical Co. (\#760151). Basically, the COX activity was evaluated by utilizing the peroxidase component of cyclooxygenases. The peroxidase activity is measured colorimetrically by monitoring the 
Table I. Antiproliferative activity of ISL and wogonin, $\mathrm{IC}_{50}$, on LNCAP and DU-145.

\begin{tabular}{lcc}
\hline Cell line & ISL $(\mu \mathrm{M})$ & Wogonin $(\mu \mathrm{M})$ \\
\hline LNCaP & $23.3 \pm 3.43$ & $29.90 \pm 5.28$ \\
DU-145 & $15.7 \pm 2.86$ & $71.90 \pm 10.21$ \\
\hline
\end{tabular}

appearance of oxidized N,N,N',N'-tetramethyl-p-phenylenediamine (TMPD) at $590 \mathrm{~nm}$.

\section{Results}

Antiproliferative effect of ISL and wogonin on prostate cancer cell lines. The inhibitory effect of ISL and wogonin on cancer cell growth was evaluated by the MTT assay. Table I summarizes the $\mathrm{IC}_{50}$ of the two reagents on the two prostate cancer cell lines LNCaP and DU-145. ISL and wogonin exhibited similar antiproliferative activity against LNCaP; however, the antiproliferative activity of ISL against DU-145 is about 5 times stronger than that of wogonin. The cytotoxicity effect of baicalein, baicalin and oridonin were reported previously (27-30).

Apoptosis of prostate cancer cells - changes in morphology induced by ISL and wogonin. Fig. 1 displays the morphology of prostate cancer cell lines, LNCaP and DU-145, in the absence and presence of ISL and wogonin at concentrations of $8 \mu \mathrm{g} / \mathrm{ml}$ and $10 \mu \mathrm{g} / \mathrm{ml}$, respectively. Mitotic figures and apoptotic cells were occasionally observed. Numerous apoptotic cells characterized by highly condensed chromatin and nuclear fragmentation are clearly seen in Fig. 1. It is noteworthy that wogonin induced a profound apoptotic effect on both LNCaP and DU-145 notwithstanding the difference between the two cell lines in $\mathrm{IC}_{50}$ values. Additionally, the apoptotic cell populations of the two cell lines were observed in DAPI stained cell cycle distribution following the treatment of ISL and wogonin for $48 \mathrm{~h}$, respectively (data not shown).

Effect of ISL and wogonin on prostate cancer cell cycle. ISL induced differential cell cycle changes in LNCaP and DU-145 after $24 \mathrm{~h}$. Fig. 2 shows the modulation of cell cycle by ISL at various concentrations at $48 \mathrm{~h}$. At a relatively low concentration $(4 \mu \mathrm{g} / \mathrm{ml})$, ISL prolonged $\mathrm{G}_{1}$ phase in LNCaP. However, higher concentrations of ISL $(8 \mu \mathrm{g} / \mathrm{ml})$ caused a $\mathrm{G}_{2} \mathrm{M}$ phase arrest.

Interestingly, this phenomenon was not observed in DU-145. A very significant $\mathrm{G}_{2} \mathrm{M}$ phase arrest in DU-145 was detected at concentrations higher than $4 \mu \mathrm{g} / \mathrm{ml}$. Similar to ISL, wogonin exerted a more profound cell cycle modulation on DU-145 than on LNCaP under similar concentration. A significant $\mathrm{G}_{2} \mathrm{M}$ cell population of DU-145 was prolonged by the treatment of $25.8 \mu \mathrm{g} / \mathrm{ml}$ wogonin. While the same effect on LNCaP was negligible.

Down-regulation of androgen-receptor $(A R)$ protein by oridonin and ISL. AR protein expression in LNCaP was measured by Western blot analysis. Fig. 3 shows the protein levels detected following oridonin, wogonin and ISL treatment of cells. The decrease in AR protein is both concentration and time-dependent. In the presence of $15.6 \mu \mathrm{M}$ $(8 \mu \mathrm{g} / \mathrm{ml})$ of ISL, the expression of AR protein was undetectable at $48 \mathrm{~h}$. Similarly, there was a large decrease in AR concentration $(>50 \%)$ by oridonin at $14.5 \mu \mathrm{M}$.

Down-regulation of androgen-receptor $(A R)$ protein by oridonin detected by flow cytometry. To confirm the Western blot result, flow cytometric method was used to determine
LNCaP

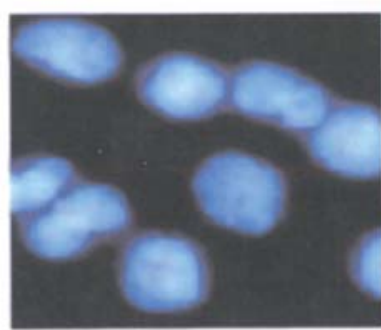

Control

DU-145

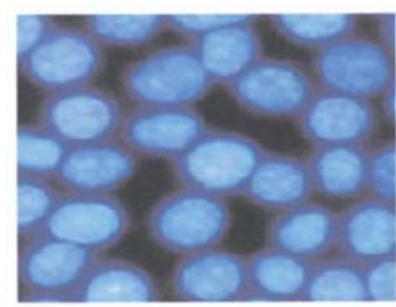

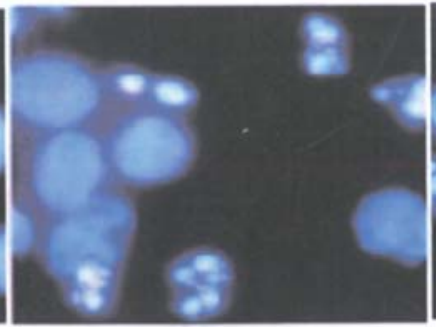

Wogonin $10 \mu \mathrm{g} / \mathrm{ml}(35 \mu \mathrm{M})$

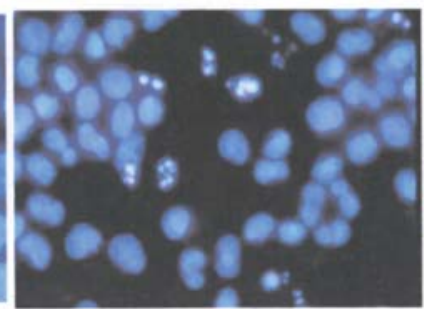

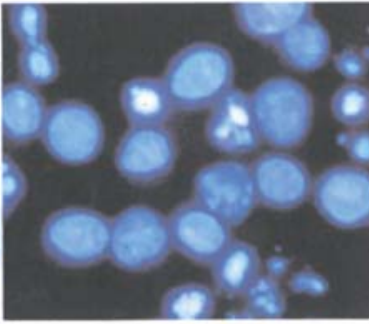

ISL $8 \mu \mathrm{g} / \mathrm{ml}(31.2 \mu \mathrm{M})$

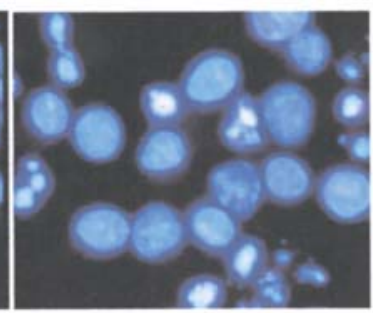

Figure 1. Apoptosis of LNCaP induced by ISL and wogonin as shown by fluorescence microscope. 

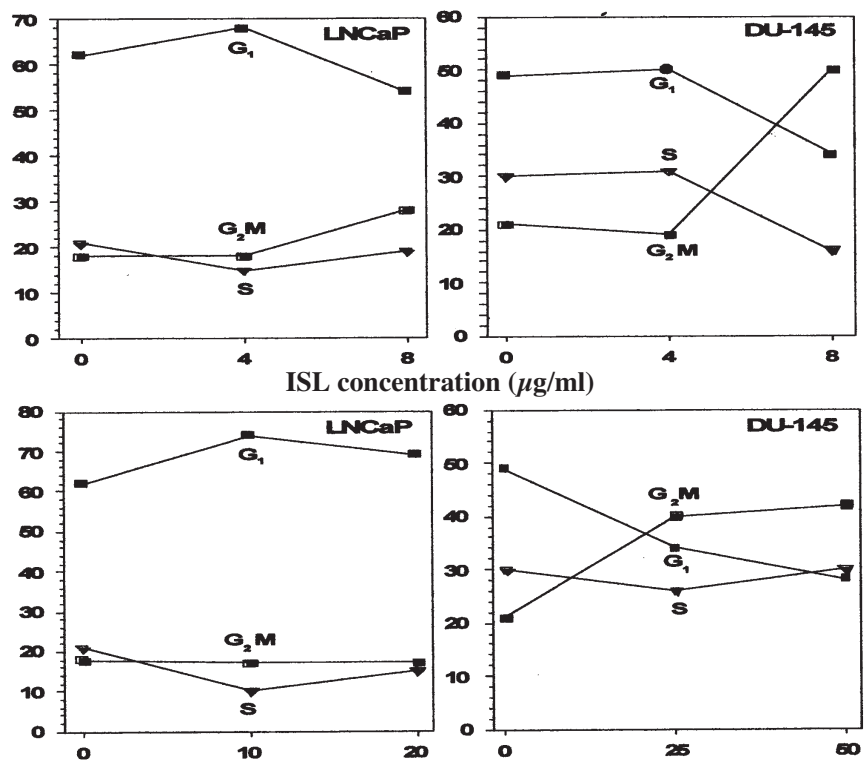

Figure 2. Concentration dependence of ISL and wogonin on the effect of cell cycle distribution in LNCaP and DU-145 at $48 \mathrm{~h}$. Cells were stained with DAPI.

\section{Down Regulation of AR}

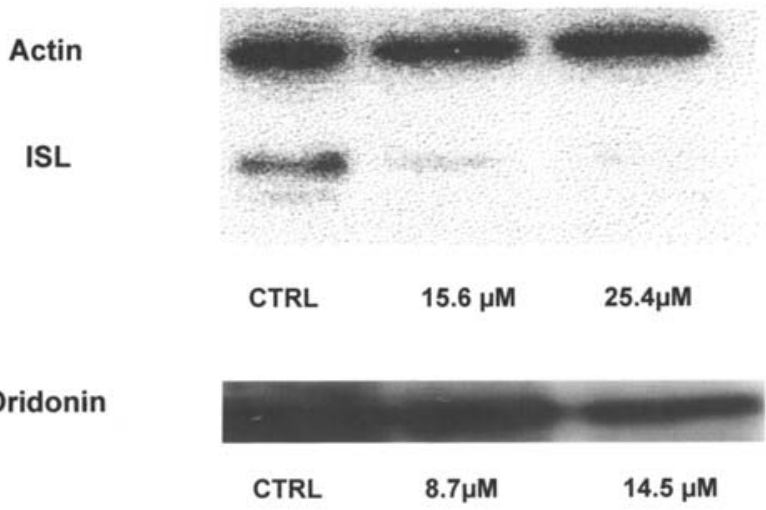

Figure 3. Western blot analysis of AR concentration in LNCaP affected by oridonin, ISL and wogonin at $48 \mathrm{~h}$.

the effect of oridonin on AR level in LNCaP. Fig. 4 shows the reduction in AR level by oridonin as a function of concentration. This result is consistent with the findings measured by Western blot shown in Fig. 3. The AR level was measured by two different fluorescence probes: a) green fluorescence of FITC binding to AR protein via monoclonal antibody; and b) red fluorescence of PI stain on DNA, which was used in the analysis of $G_{1}$ cell population.

Down-regulation of PSA by ISL and wogonin measured by Western blot analysis. PSA proteins expressed in LNCaP or secreted into the medium were measured by Western blot analysis. Fig. 5 shows the protein levels detected at two concentrations of the agents tested. In the presence of $31.8 \mu \mathrm{M}$ of ISL, the intracellular and extracellular PSA protein was undetectable. At $70.4 \mu \mathrm{M}$ of wogonin, a large decrease in PSA (in cells and in medium) was observed.

\section{AR by flow cytometry}

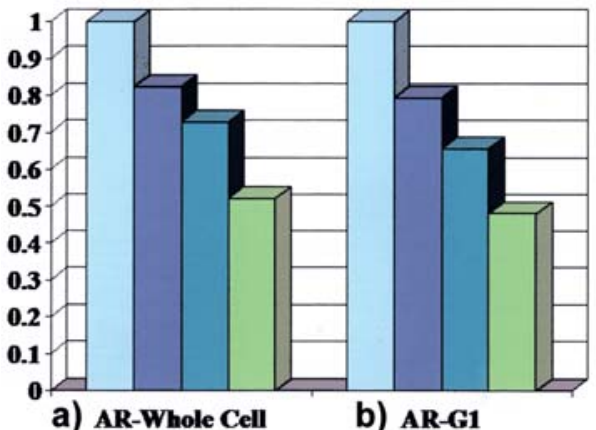

$\square$ CTRL_48h

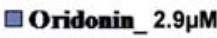

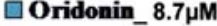

$\square$ Oridonin_14.5 $\mathrm{M}$

Figure 4. Flow cytometric measurement of $\mathrm{AR}$ protein in $\mathrm{LNCaP}$ affected by oridonin as a function of concentration. (a) AR level was detected by FITC fluorescence; (b) AR level was detected by $\mathrm{G}_{1}$ cell population which was analyzed using PI stained DNA.

\section{PSA Reduction by ISL and Wogonin}

ISL

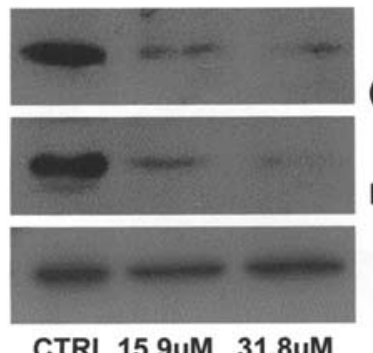

\section{Wogonin}

PSA (medium) PSA (cell) actin

CTRL $15.9 \mu \mathrm{M} \quad 31.8 \mu \mathrm{M}$

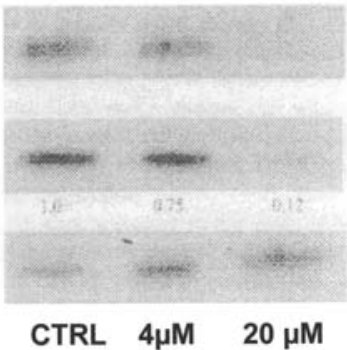

Figure 5. Western blot analysis of intracellular and extra cellular concentrations of PS Aprotein in LNCaP modulated by ISL and wogonin at two concentrations.

\section{Inhibition of COX-1, 2}

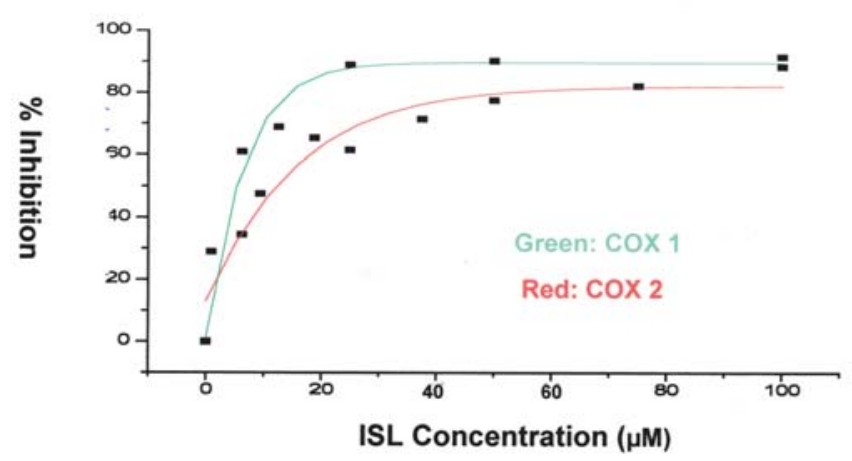

Figure 6. Inhibition of ISL on the enzymatic activity of cyclooxygenase 1 and 2 as a function of ISL concentration. Green, inhibition of COX 1; red, inhibition of COX 2 .

Inhibition of COX 1 and COX 2 by ISL. Among the compounds tested, ISL showed the strongest inhibition on 
the COX enzyme activity. Fig. 6 displays the dose response curves of ISL on COX 1 (green) and COX 2 (red). The curves were graphed using non-linear regression curve fit (Harvard graphic). It seems that ISL is slightly more sensitive towards COX $1\left(\mathrm{IC}_{50} \sim 8 \mu \mathrm{M}\right)$ than $\mathrm{COX} 2\left(\mathrm{IC}_{50} \sim 12 \mu \mathrm{M}\right)$.

\section{Discussion}

It is well established that the development and progression of prostate cancer is dependent on androgen and the AR. In as much as AR plays a complex and diversified role in prostate cancer, recent studies have demonstrated its important role in the transition of prostate cancer from the androgen dependent to independent stage (3-15). Yuan et al further showed that AR was also a critical player for cell cycle progression in androgen-independent CWR22 prostate cancer cells (31).

The sensitization of AR signaling pathways in HRPC is caused by several factors. Using microarray-based profiling of prostate cancer xenograft models, Chen et al demonstrated that androgen receptor antagonists converted to agonistic activity in cells with increased androgen receptor levels (11). This antagonist-agonist conversion was associated with alterations in the recruitment of coactivators and corepressors to the promoters of androgen receptor target genes. Thus, the increase in AR mRNA and protein was both necessary and sufficient to convert prostate cancer growth from a hormone-sensitive to hormone-refractory (HRPC) stage. The other contributing factor to HRPC is AR mutation. Dehm et al showed a mutation in molecular structure of AR leads HRPC cells to be independent of the ligand binding and AF-2 region. Instead, HRPC cells become $\mathrm{N}$-terminal domain dependent (10). These studies consistently demonstrate the critical function of $\mathrm{AR}$ in androgen-independent prostate cancer is distinct from its classical transcriptional or nontranscriptional functions.

In line with the above, results obtained from this study seem to support our previous theory that down-regulation of AR by various phyto-chemicals in PC-SPES is one of the mechanisms that contributed to its anti-HRPC activity (26-30,32,33).

It is noted that oridonin has a very different chemical structure and physico-chemical properties compared to those of ISL, wogonin and baicalin. The latter compounds belong to the chemical group of polyphenols or flavonoids. Polyphenols extracted from many plants have been shown to be either chemopreventive or antitumor agents in a wide range of carcinogenesis models. By flow cytometric analysis, the polyphenol fraction was demonstrated to induce $G_{0} / G_{1}$ cell growth arrest and cell apoptosis in DU-145 and PC-3 triggered by caspase- 3 activation $(34,35)$. Since oridonin (36,37), baicalein, wogonin (38-40) and ISL (41) are known to stimulate caspase- 3 activation, the apoptosis of LNCaP and DU-145 observed in Fig. 1 was likely caused by the same mechanism.

In addition to caspase- 3 activators, baicalein, wogonin, isoliquiritigenin and oridonin are also potent inhibitors of

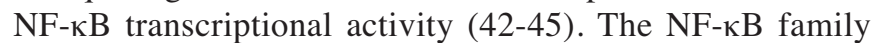
of transcription factors has been shown to be constitutively activated in various human malignancies.
An inverse correlation between androgen receptor (AR) status and NF- $\mathrm{KB}$ activity was observed in prostate cancer cell lines (46-51). The study by Suh et al showed that NF-кB promoted cell growth and proliferation in prostate cancer cells by regulating expression of genes such as c-myc, cyclin D1 and IL-6. Furthermore, NF-кB-mediated expression of genes involved in angiogenesis (IL-8, VEGF), and invasion and metastasis (MMP 9, uPA, uPA receptor) may further contribute to the progression of androgen depleted prostate cancer. In view of the above, the antiproliferative activity of these phytochemicals is partly due to their inhibitory action on the transactivation of NF- $\mathrm{KB}$ and to the depletion of AR.

In this study, we have also shown that ISL is a potent COX 1 and COX 2 enzyme inhibitor. These type of inhibitors (NSAIDs) have been reported to reduce prostate cancer risk due to the activarion of COX-2 gene in progressive prostate cancer (52-58). Whether there is a direct relationship between the anti-inflammatory nature of ISL and its AR depleting activity remains to be investigated.

Finally, the depletion of PSA observed in the LNCaP cell line caused by ISL, oridonin and wogonin can be understood in terms of their ability to down-regulate AR. Since PSA gene is positively regulated via binding of AR to the androgenresponsive elements in the promoter of PSA, it is expected that reduction of AR will lead to a decline in PSA (59-61).

Taken together, we have shown that the phyto-chemicals oridonin, ISL and wogonin exert antiproliferative activity via modulation of cell cycle. Some of these compounds down-regulate the protein expression of AR and PSA in LNCaP. In view of the potential benefit of these agents in controlling HRPC progression, more study is in progress to understand the in vitro and in vivo mechanisms.

\section{Acknowledgements}

This project was supported by the CaPCURE Research Award.

\section{References}

1. American Cancer Society. Cancer Facts Figures 56: 106-130, 2006.

2. Isaacs $\mathbf{J}$ and Isaacs WB: Androgen receptor outwits prostate cancer drugs. Nat Med 10: 26-27, 2004.

3. Edwards J and Bartlett JM: The androgen receptor and signaltransduction pathways in hormone-refractory prostate cancer. Part 2: androgen-receptor cofactors and bypass pathways. BJU Int 95: 1327-1335, 2005.

4. Quayle SN, Mawji NR, Wang J and Sadar MD: Androgen receptor decoy molecules block the growth of prostate cancer. Proc Natl Acad Sci USA 104: 1331-1336, 2007.

5. Hendriksen PJ, Dits NF, Kokame K, et al: Evolution of the androgen receptor pathway during progression of prostate cancer. Cancer Res 66: 5012-2020, 2006.

6. Shi Y, Chatterjee SJ, Brands FH, Shi SR, Pootrakul L, Taylor CR, Datar R and Cote RJ: Role of coordinated molecular alterations in the development of androgen-independent prostate cancer: an in vitro model that corroborates clinical observations. BJU Int 97: 170-178, 2006.

7. Sato M, Johnson M, Zhang L, Gambhir SS, Carey M and $\mathrm{Wu}$ L: Functionality of androgen receptor-based gene expression imaging in hormone refractory prostate cancer. Clin Cancer Res 11: 3743-3749, 2005.

8. Berger R, Lin DI, Nieto M, Sicinska E, Garraway LA, Adams H, Signoretti S, Hahn WC and Loda M: Induction and activation of Her-2/neu occurs in an androgen-depleted envi-ronment or as a result of AR inactivation, promoting ablation-resistant survival of prostate cancer cells. Cancer Res 66: 5723-5728, 2006 . 
9. Desai SJ, Ma AH, Tepper CG, Chen HW and Kung HJ: Inappropriate activation of the androgen receptor by non-steroids: involvement of the Src kinase pathway and its therapeutic implications. Cancer Res 66: 10449-10459, 2006.

10. Dehm SM and Tindall DJ: Ligand-independent androgen receptor activity is activation function-2 independent and resistant to antiandrogens in androgen refractory prostate cancer cells. J Biol Chem 281: 27882-27893, 2006.

11. Chen CD, Welsbie DS, Tran C, et al: Molecular determinants of resistance to antiandrogen therapy. Nat Med 10: 33-39, 2004.

12. Kasper S and Cookson MS: Mechanisms leading to the development of hormone-resistant prostate cancer. Urol Clin North Am 33: 201-210, 2006.

13. Taplin ME: Drug insight: role of the androgen receptor in the development and progression of prostate cancer. Nat Clin Pract Oncol 4: 236-244, 2007

14. Scher HI and Sawyers CL: Biology of progressive, castrationresistant prostate cancer: directed therapies targeting the androgen-receptor signaling axis. J Clin Oncol 23: 8253-8261, 2005.

15. Chen L, Meng S, Wang H, Bali P, Bai W, Li B, Atadja P, Bhalla $\mathrm{KN}$ and $\mathrm{Wu} \mathrm{J}$ : Chemical ablation of androgen receptor in prostate cancer cells by the histone deacetylase inhibitor LAQ824. Mol Cancer Ther 4: 1311-1319, 2005.

16. Di Paola RS, Zhang H, Lambert GH, Meeker R, Licitra E, Rafi MM, Zhu BT, Spaulding H, Goodin S, Toledano MB, Hait WN and Gallo MA: Clinical and biological activity of an estrogenic herbal combination (PC SPES) in prostate cancer. N Engl J Med 339: 785-791, 1998.

17. De la Tallie A, Hayek OR, Buttyan R, Bagiella E, Burchardt M and Katz AE: Effects of PC-SPES in prostate cancer: a preliminary investigation on human cell lines and patients. Br J Urol Int 84: 845-850, 1999.

18. Kubota T, Hisatake J, Hisatake Y, Said JW, Chen SS, Holden S, Taguchi $\mathrm{H}$ and Koeffler HP: PC-SPES: a unique inhibitor of proliferation of prostate cancer cells in vitro and in vivo. Prostate 42: 163-171, 2000.

19. Small EJ, Frahlich RB, Shinihara K, Grossfeld G, Rozenblat Z, Kevin Kelly W, Carry M and Reese DM: Perspective trial of the herbal supplement PC SPES in patients with progressive prostate cancer. J Clin Oncol 18: 3595-3603, 2000.

20. Oh WK, George DJ, Hackmann K, Manola J and Kantoff PH: Activity of the herbal combination, PC-SPES, in the treatment of patients with androgen-independent prostate cancer. Urology 57: 122-126, 2001

21. Bonham MJ, Galkin A, Montgomery B, Stahl WL, Agus D and Nelson PS: Effects of the herbal extract PC-SPES on microtubule dynamics and paclitaxel-mediated prostate tumor growth inhibition. J Natl Cancer Inst 94: 1641-1647, 2002.

22. Marks LS, Di Paola RS, Nelson P, Chen S, Heber D, Belldegrun AS, Lowe FC, Fan J, Leaders FE Jr, Pantuck AJ and Tyler VE: PC-SPES: herbal formulation for prostate cancer. Urology 60: 369-375, 2002.

23. Oh WK, Kantoff PW, Weinberg V, Jones G, Rini BI, Derynck MK, Bok R, Smith MR, Bubley GJ, Rosen RT, Di Paola RS and Small EJ: Prospective, multicenter, randomized phase II trial of the herbal supplement, PC-SPES, and diethylstilbestrol in patients with androgen-independent prostate cancer. J Clin Oncol 22: 3705-3712, 2004.

24. Wadsworth T, Poonyagariyagorn H, Sullivan E, Koop D and Roselli CE: In vivo effect of PC-SPES on prostate growth and hepatic CYP3A expression in rats. J Pharmacol Exp Ther 306: 187-194, 2003.

25. Walsh PC: American Society of Clinical Oncology recommendations for the initial hormonal management of androgensensitive metastatic, recurrent or progressive prostate cancer. J Urol 173: 1966, 2005.

26. Hsieh TC, Chen SS, Wang X and Wu JM: Regulation of androgen receptor (AR) and prostate specific antigen (PSA) expression in the androgen-responsive human prostate $\mathrm{LNCaP}$ cells by ethanolic extracts of the Chinese herbal preparation, PC-SPES. Biochem Mol Biol Int 42: 535-544, 1997.

27. Chen S, Ruan Q, Bedner E, Deptala A, Wang X, Hsieh TC, Traganos F and Darzynkiewicz Z: Effects of the flavonoid baicalin and its metabolite baicalein on androgen receptor expression, cell cycle progression and apoptosis of prostate cancer cell lines. Cell Prolif 34: 293-304, 2001.

28. Ikezoe T, Chen SS, Heber D, Taguchi H and Koeffler HP: Baicalin is a major component of PC-SPES which inhibits the proliferation of human cancer cells via apoptosis and cell cycle arrest. Prostate 49: 285-292, 2001.
29. Ikezoe T, Chen SS, Tong XJ, Heber D, Taguchi H and Koeffler HP: Oridonin induces growth inhibition and apoptosis of a variety of human cancer cells. Int J Oncol 23: 1187-1193, 2003.

30. Chen S, Gao J, Halicka HD, Huang X, Traganos F and Darzynkiewicz Z: The cytostatic and cytotoxic effects of oridonin (Rubescenin), a diterpenoid from Rabdosia rubescens, on tumor cells of different lineage. Int J Oncol 26: 579-588, 2005.

31. Yuan X, Li T, Wang H, Zhang T, Barua M, Borgesi RA, Bubley GJ, Lu ML and Balk SP: Androgen receptor remains critical for cell-cycle progression in androgen-independent CWR22 prostate cancer cells. Am J Pathology 169: 682-696, 2006.

32. Darzynkiewicz Z, Traganos F, Wu JM and Chen S: Chinese herbal mixture PC SPES in treatment of prostate cancer. (Review). Int J Oncol 7: 729-736, 2000.

33. Chen S: In vitro mechanism of PC SPES. Urology 58 (Suppl 1): 28-35, 2001.

34. Queires LC, Fauvel-Lafetve F, Terry S, De la Taille A, Kouyoumdjian JC, Chopin DK, Vacherot F, Rodrigues LE and Crepin M: Polyphenols purified from the Brazilian aroeira plant (Schinus terebinthifolius, Raddi) induce apoptotic and autophagic cell death of DU145 cells. Anticancer Res 26: 379-387, 2006.

35. Sanchez AM, Sanchez MG, Malagarie-Cazenave S, Olea N and Diaz-Laviada I: Capsaicin, the pungent ingredient of hot chilli pepper, has been recently shown to induce apoptosis in PC-3 via activation of caspase 3. Apoptosis 11: 89-99, 2006.

36. Liu JJ, Huang RW, Lin DJ, Wu XY, Peng J, Pan XL, Lin Q, Hou M, Zhang MH and Chen F: Antiproliferation effects of oridonin on HPB-ALL cells and its mechanisms of action. Am J Hematol 81: 86-94, 2006.

37. Zhang JF, Liu JJ, Liu PQ, Lin DJ, Li XD and Chen GH: Oridonin can inhibit cell growth by induction of apoptosis in BEL-7402 cells via activation of caspase-3 as well as downregulation of $\mathrm{Bcl}-2$ and up-regulation of $\mathrm{Bax}$ expression. Hepatol Res 35: 104-110, 2006.

38. Ma Z, Otsuyama K, Liu S, Abroun S, Ishikawa H, Tsuyama N, Obata M, Li FJ, Zheng X, Maki Y, Miyamoto K and Kawano MM: Baicalein, a component of Scutellaria radix from Huang-Lian-Jie-Du-Tang (HLJDT), leads to suppression of proliferation and induction of apoptosis in human myeloma cells. Blood 105: 3312-3318, 2005.

39. Park EJ, Zhao YZ, Lian L, Kim YC and Sohn DH: Wogonin in $\mathrm{S}$. baicalensis selectively induced apoptosis in T-HSC/Cl-6 cells via caspase-3 and caspase-9 activation. Plant Med 71: 885-887, 2005.

40. Chen YC, Shen SC, Lee WR, Lin HY, Ko CH, Shih CM and Yang LL: Wogonin and fisetin induction of apoptosis through activation of caspase 3 cascade and alternative expression of p21 protein in hepatocellular carcinoma cells SK-HEP-1. Arch Toxicol 76: 351-359, 2002

41. Jung JI, Lim SS, Choi HJ, Cho HJ, Shin HK, Kim EJ, Chung WY, Park KK and Park JH: Isoliquritigenin induces apoptosis by depolarizing mitochondrial membranes in prostate cancer cells. J Nutr Biochem 17: 89-96, 2006.

42. Ikezoe T, Yang Y, Bandobashi K, Saito T, Takemoto S, Machida H, Togitani K, Koeffler HP and Taguchi H: Oridonin, a diterpenoid purified from Rabdosia rubescens, inhibits the proliferation of cells from lymphoid malignancies in association with blockade of the NF-kappa B signal pathways. Mol Cancer Ther 4: 578-586, 2005.

43. Tang NY, Yang JS, Chang YH, Lu HF, Hsia TC, Lin WC and Chung JG: Effects of wogonin on the levels of cytokines and functions of leukocytes associated with NF-kappa B expression in Sprague-Dawley rats. In Vivo 20: 527-532, 2006.

44. Lee SO, Jeong YJ, Yu MH, Lee JW, Hwangbo MH, Kim CH and Lee IS: Wogonin suppresses TNF-alpha-induced MMP-9 expression by blocking the NF-kappaB activation via MAPK signaling pathways in human aortic smooth muscle cells. Biochem Biophys Res Commun 351: 118-125, 2006.

45. Kwon HM, Choi YJ, Choi JS, Kang SW, Bae JY, Kang IJ, Jun JG, Lee SS, Lim SS and Kang YH: Blockade of cytokineinduced endothelial cell adhesion molecule expression by licorice isoliquiritigenin through NF-kappaB signal disruption. Exp Biol Med 232: 235-245, 2007.

46. Suh J and Rabson AB: NF-kappaB activation in human prostate cancer: important mediator or epiphenomenon? J Cell Biochem 91: 100-117, 2004. 
47. Bhuiyan MM, Li Y, Banerjee S, Ahmed F, Wang Z, Ali S and Sarkar FH: Down-regulation of androgen receptor by 3,3'diindolylmethane contributes to inhibition of cell proliferation and induction of apoptosis in both hormone-sensitive LNCaP and insensitive $\mathrm{C} 4-2 \mathrm{~B}$ prostate cancer cells. Cancer Res 66 : 10064-10072, 2006.

48. Lee SO, Lou W, Nadiminty N, Lin X and Gao AC: Requirement for NF-(kappa)B in interleukin-4-induced androgen receptor activation in prostate cancer cells. Prostate 64: 160-167, 2005.

49. Zerbini LF, Wang Y, Cho JY and Libermann TA: Constitutive activation of nuclear factor B p50/p65 and Fra- 1 and JunD is essential for deregulated interleukin 6 expression in prostate cancer. Cancer Res 63: 2206-2215, 2003.

50. Armstrong K, Robson CN and Leung HY: NF-kappaB activation up-regulates fibroblast growth factor 8 expression in prostate cancer cells. Prostate 66: 1223-1234, 2006.

51. Peant B, Diallo JS, Lessard L, Delvoye N, Le Page C, Saad F and Mes-Masson AM: Regulation of IkappaB kinase epsilon expression by the androgen receptor and the nuclear factorkappaB transcription factor in prostate cancer. Mol Cancer Res 5: 87-94, 2007.

52. Narayanan BA, Narayanan NK, Pittman B and Reddy BS: Regression of mouse prostatic intraepithelial neoplasia by non-steroidal anti-inflammatory drugs in the transgenic adenocarcinoma mouse prostate M. Clin Cancer Res 10: 7727-7737, 2004.

53. Narayanan BA, Narayanan NK, Davis L and Nargi D: RNA interference-mediated cyclooxygenase- 2 inhibition prevents prostate cancer cell growth. Mol Cancer Ther 5: 1117-1125, 2006.

54. Hughes-Fulford M, Li CF, Boonyaratanakornkit J and Sayyah S: Arachidonic acid activates phosphatidylinositol 3-kinase signaling and induces gene expression in prostate cancer. Cancer Res 66: 1427-1433, 2006.
55. Asirvatham AJ, Schmidt M, Gao B and Chaudhary J: Androgens regulate the immune/inflammatory response and cell survival pathways in rat ventral prostate epithelial cells. Endocrinology 147: 257-271, 2005.

56. Cohen BL, Gomez P, Omori Y, et al: Cyclooxygenase-2 (COX-2) expression is an independent predictor of prostate cancer recurrence. Int J Cancer 119: 1082-1087, 2006.

57. Mahmud SM, Tanguay S, Begin LR, Franco EL and Aprikian AG: Non-steroidal anti-inflammatory drug use and prostate cancer in a high-risk population. Eur J Cancer Prev 15: 158-164, 2006.

58. Miyamoto H, Altuwaijri S, Cai Y, Messing EM and Chang C: Inhibition of the Akt, cyclooxygenase-2, and matrix metalloproteinase-9 pathways in combination with androgen deprivation therapy: potential therapeutic approaches for prostate cancer. Mol Carcinog 44: 1-10, 2005.

59. Thelen P, Peter T, Hunermund A, et al: Phytoestrogens from Belamcanda chinensis regulate the expression of steroid receptors and related cofactors in $\mathrm{LNCaP}$ prostate cancer cells. BJU Int 100: 199-203, 2007.

60. Arnold JT, Liu X, Allen JD, Le H, McFann KK and Blackman MR: Androgen receptor or estrogen receptor-beta blockade alters DHEA-, DHT-, and E(2)-induced proliferation and PSA production in human prostate cancer cells. Prostate 67: 1152-1162, 2007

61. Mostaghel EA, Page ST, Lin DW, et al: Intraprostatic androgens and androgen-regulated gene expression persist after testosterone suppression: therapeutic implications for castration-resistant prostate cancer. Cancer Res 67: 5033-5041, 2007. 